\title{
Current estimates of goose population sizes in western Europe, a gap analysis and an assessment of trends
}

\author{
Aktuella skattningar av gåsbeståndens storlek $i$ västra Europa, analys av \\ kunskapsluckor och utvärdering av trender
}

\author{
ANTHONY D. FOX, BART S. EBBINGE, CARL MITCHELL, THOMAS HEINICKE, \\ TOMAS AARVAK, KENDREW COLHOUN, PREBEN CLAUSEN, SERGEY DERELIEV, \\ SÁNDOR FARAGÓ, KEES KOFFIJBERG, HELMUT KRUCKENBERG, \\ MAARTEN J. J. E. LOONEN, JESPER MADSEN, JOHAN MOOIJ, PETR MUSIL, LEIF NILSSON, \\ STEFAN PIHL \& HENK VAN DER JEUGD
}

\begin{abstract}
We estimated the size of 30 defined populations of geese wintering in the Western Palearctic (including five released or reintroduced populations of three species). Fourteen populations were accurately estimated from almost full count coverage or robust sampling and ten were well estimated based on more than $50 \%$ of their total being counted. An estimated 5.03 million geese wintered in January 2009, up on 3.10 million in January 1993. Only two populations numbered less than 10,000 birds (Scandinavian Lesser White-fronted Goose and Svalbard/Greenland Light-bellied Brent Goose, the former being critically small within restricted range). Eighteen populations numbered 10,000-100,000, eight 100,000 $1,000,000$ and the largest 1.2 million individuals. Of 21 populations with known longer term trends, 16 are showing significant exponential increases, 4 are stable and one declining. Amongst these same populations, five are declining since the 1990s. Long term declines in productivity were found in 7 out of 15 populations. Amongst most of the 11 populations for which data exist, there were no significant long-term trends in annual adult survival. Improved monitoring, including demographic, is required to retain populations in favorable conservation status.
\end{abstract}

Anthony D. Fox, Department of Wildlife Ecology and Biodiversity, National Environmental Research Institute, Aarhus University, Kalø, Grenåvej 14, DK-8410 Rønde, Denmark.E-mail:tfo@dmu.dk.

Bart S. Ebbinge, P.O. Box 47, Alterra, NL-6700 AA, Wageningen, Netherlands.

Carl Mitchell, Wildfowl \& Wetlands Trust, Slimbridge, Gloucester, GL2 7BT, UK.

Thomas Heinicke, Gingster Strasse 18, D-18573, Germany.

Tomas Aarvak, Sandgata 30b, N-7012 Trondheim, Norway.
Kendrew Colhoun, RSPB Northern Ireland Office, Belvoir Park Forest, Belfast BT8 7QT, United Kingdom. Preben Clausen, Department of Wildlife Ecology and Biodiversity, National Environmental Research Institute, Aarhus University, Kalø, Grenåvej 14, DK-8410 Rønde, Denmark.

Sergey Dereliev, UNEP/AEWA Secretariat, UN-Campus Bonn, Hermann-Ehlers-Strasse 10, D-53113 Bonn, Germany.

Sándor Faragó, University of West Hungary, Faculty of Forestry, Institute of Wildlife Management, H-9400 Sopron, Ady Endre út 5, Hungary.

Kees Koffijberg, SOVON, PO Box 6521, NL-6503 GA Nijmegen, The Netherlands.

Helmut Kruckenberg, Am Steigbügel 3. D-27283 Verden, Germany.

Maarten J. J. E. Loonen, Department of Arctic and Antarctic Studies, University of Groningen, Artic Centre A-weg 30, NL-9718 CW Groningen, The Netherlands. Jesper Madsen, Department of Arctic Environment, National Environmental Research Institute, Aarhus University, PO Box 358, Frederiksborgvej 399, DK 4000 Roskilde, Denmark.

Johan Mooij, Biologische Station in Kreis Wesel, Freybergweg 9, D-46483 Wesel, Germany.

Petr Musil, Department of Zoology, Faculty of Sciences, Charles University, Viničná 7, CZ-12844 Praha 2, Czech Republic.

Leif Nilsson, Department of Animal Ecology, University of Lund, Ekologihuset, S-223 62 Lund, Sweden.

Stefan Pihl, Department of Wildlife Ecology and Biodiversity, National Environmental Research Institute, Aarhus University, Kalø, Grenåvej 14, DK-8410 Rønde, Denmark.

Henk van der Jeugd, Vogeltrekstation, Postbus 40, NL6666 ZG Heteren, Netherlands. 


\section{Introduction}

There are 15 recognised species of geese, ascribed to two genera (Anser and Branta) in the world, of which 8 are considered to occur naturally in the Western Palearctic region. Amongst these, there are 27 recognised "populations" or "flyways", mostly as defined in Madsen et al. (1999). Knowing about the distribution and abundance of geese is important for a number of reasons. Firstly, international legislation and conventions (such as Ramsar, Bonn and Biodiversity Conventions) require such information as indicators of biodiversity and wetland health, most notably to provide population estimates as a basis to providing " $1 \%$ criteria", whereby a site regularly supporting $1 \%$ or more of a waterbird population qualifies as being of international importance under the Ramsar Convention on Wetlands. Secondly, given many geese are popular quarry species, international legislation (such as the European Union Birds Directive) requires hunting of birds be undertaken in a manner that "does not jeopardize conservation efforts in their distribution area". The African-Eurasian Waterbird Agreement (AEWA) also requires that "Parties shall ensure that any use of migratory waterbirds is based on an assessment of the best available knowledge of their ecology and is sustainable for the species as well as for the ecological systems that support them". Thirdly, many (but by no means all) goose populations have become increasingly reliant on agricultural land upon which to feed, especially during the non-breeding season, when the geese predate monocultures of specially bred high-quality forage grasses, cereals and root crops, bringing conflict with farmers. Geese therefore have long had a particular association with people which means that we have more information relating to their abundance over long time scales than for many other avian species. Here, we exploit this association and knowledge to update our estimates of the population size and trends of Western Palearctic geese from those of Delany \& Scott (2006), highlighting the gaps in our current knowledge and areas in need of particular improvement.

\section{Methods}

\section{Defining populations}

We define goose populations to aid the administration of their effective conservation management rather than in any strict biological sense. For this reason, we use the traditional definitions of bio-ge- ographical populations (after Scott \& Rose 1996, Madsen et al. 1999, Delany \& Scott 2002) which are units within species that share breeding, staging and wintering areas (summarised in Table 2).

\section{Assessing total population size}

The goose populations that nest in the arctic from north-eastern Canada across to northern Siberia and throughout Europe as far south as Turkey all gather to winter in the Western Palearctic region. Because breeding areas are vast and generally inaccessible, summering densities low, and geese are generally more concentrated into smaller areas outside of the breeding season, population assessment surveillance has traditionally taken place outside of the breeding period. Goose numbers are assessed through a variety of methods, which makes the assessment of annual total numbers and changes over time difficult to compile. Generally, counting was originally initiated on a local or national basis, and mechanisms to coordinate these efforts internationally have followed as knowledge about flyway interactions and migration routes have become known, mainly as a result of ringing recoveries and/or resightings of marked individuals. Counts on the ground generally involve observers with considerable experience of counting relatively large numbers of birds, assessing flocks and flock size and assigning mixed groups to species. Counting roosting flocks coming to or from major night time roosts has advantages, because whilst large aggregations make assessment difficult (because of the specialist ability needed to count large groups of moving birds), this technique minimises double counting and missed birds involved with counting similar and often highly mobile numbers scattered over large feeding areas by day. National surveys are now generally coordinated by research institutes, government or non-governmental organisations that are responsible for co-ordination, quality control, collation, analysis and reporting of the data, often to the responsible statutory agencies involved in nature conservation monitoring. However, physically, the counts on the ground are invariably undertaken largely by networks of highly experienced volunteers, supplemented where necessary by relatively few professionals.

Uniquely amongst avian surveillance programmes, a few populations have been surveyed annually since before the 1950 s, most notably in north-western Europe, whereas coverage in eastern and south-eastern parts of the range is more recent and less extensive. Nevertheless, to date 60 coun- 
tries have contributed mid winter counts of geese via the Wetlands International (WI) International Waterbird Census (IWC) which contains most of the existing available data.

Traditionally, the mid-January IWC were the main source of data on geese, because other waterbirds were counted on their winter quarters at that time, resulting in large numbers of observers motivated to go out and count birds on wetlands at that time. Unless affected by hard-weather movements, turnover of geese between staging sites at this time also ensures fewer duplicated or missed counts. However, for many reasons, this method may not be suitable for all species and where it is considered more accurate assessments of total population size can be achieved during autumn or spring (when geese may be more concentrated into fewer staging areas and therefore easier to count); special coordinated population assessment counts have been undertaken at other times (e.g. Greenland White-fronted Goose Anser albifrons flavirostris in late March). Increasingly, climate change is affecting the timing and intensity of migration and this too is beginning to affect decision-making relating to the best time to assess population size on the non-breeding areas (e.g. the Iceland Greylag Goose Anser anser traditionally counted in October, but now because of delayed arrival is increasingly assessed in November and December, Mitchell 2009). For some populations, complete annual coverage is too costly so surveys are carried out at longer intervals (e.g. aerial survey is necessary to cover the Greenland Barnacle Goose Branta leucopsis population wintering in largely offshore islands in Ireland and Britain and this has been carried out at approximately 3-5 years intervals, Mitchell et al. 2008).

Historically, the Wetlands International/Species Survival Commission Goose Specialist group organised the collation of a database and via a network of national count coordinators and population coordinators produced population overviews in the major review of Madsen et al. (1999). Many of the mechanisms established prior to the review or at that time continue, providing a platform for the compilation of data on specific populations from different countries to provide an annual total. For example, in the case of the United Kingdom, populations such as the Iceland Greylag Goose and the Greenland/Icelandic Pink-footed Goose are reported annually by the Wildfowl \& Wetlands Trust (Mitchell 2009) and to service internal goose management issues, the Dutch government has organised the collation of annual population estimates for key species wintering in that country to determine whether the rate of change amongst wintering goose numbers in the Netherlands is tracking those of the flyway population as a whole (Ebbinge 2009).

However, for several populations at the present time, no coordinated coverage is organised or achieved, with the result that our assessment of their population sizes is subject to considerable uncertainty (and the subject of other analyses presented in this volume). For some areas, published data are limited and in some cases, this means that the quality of the estimates presented in this assessment are poor, or at least poorer than for others. We have attempted to provide some guidance as to the relative quality of each of the estimates to guide their reliability and utility (see below), but also as a gap analysis to indicate areas that require attention to improve the quality of the available estimates in the immediate future.

\section{Sources of population estimate data presented}

Wherever possible, the data for a given species are collated by a responsible authority which has coordinated regular counts following common protocols to generate total counts in a reasonably exhaustive and consistent manner. In the UK, the Wildfowl \& Wetlands Trust coordinates and compiles counts, and report on annual population estimates for $\mathrm{Ca}$ nadian Light-bellied Brent Geese Branta bernicla hrota (Robinson et al. 2004), Greenland Whitefronted Geese, Pink-footed Geese (see Mitchell \& Hearn 2004), Greylag Geese (see Hearn \& Mitchell 2004) and Greenland and Svalbard breeding Barnacle Geese throughout their winter range and the quality of these estimates is considered high because of the effort put into coordinated coverage of known sites, the systematic and consistent coverage achieved and the accessibility and documentation relating to the compilation of the count data. Similarly Alterra in the Netherlands coordinates the assessment of the Russian Barnacle Geese (assisted by H. van der Jeugd), Greater White-fronted Geese Anser albifrons albifrons, Dark-bellied Brent Geese Branta bernicla bernicla and with the University of Lund in Sweden contribute to that of Greylag Geese in western Europe. The Danish National Environmental Research Institute at the University of Aarhus coordinates annual reporting of the Pink-footed and Light-bellied Brent Geese that nest in Svalbard. Cross-border coordination of counts of Red-breasted Geese Branta ruficollis in the Black Sea minimises double counting in Ro- 
Table 1. The six data quality codes used in the presentation of the goose population estimates (modified after Thorup 2006).

De sex koder som används för att ange datakvalitet vid presentationen av skattningarna av gåsbeståndens storlek.

\begin{tabular}{lll}
\hline Extent of knowledge & Data underlying estimate \\
Kunskapsläge & Data bakom skattningen
\end{tabular}

mania, Ukraine and Bulgaria, but weaker coordination with other wintering resorts for this goose means that some improvement in annual estimation of this population could be achieved. For other populations, there is little or no coordination, with the result that the estimates of population size are informed assessments based on independent assessments of the available data. For some states, this means an average of recent mid-winter counts, whether complete over a series of years since 2000 or not, taking no account of the effects of hard winters or other factors causing movement between states within and between winters. Wherever possible, we rely upon expert assessments amongst the authors and specific recent reviews to provide accurate population estimates and, where possible, trends. Following Thorup (2006) we have felt the need to apply some guidance as to the data quality underlying the population estimates, based both on the quality of available data from each national scheme and the extent to which the estimates are based on real and regular counts undertaken as a surveillance programme, rather than the estimates of experts. For this reason we have adopted a very slightly modified version of Thorup's (2006) 6 point data quality codes (Table 1) which we have applied to the population estimates presented throughout this analysis.

\section{Sources of population trend data}

Where a reasonable time series exists for the populations presented, we assessed the rate of change in numbers by regressing the logarithmically transformed annual population estimate on year to give an annual (percentage) rate of change for the population. Wherever possible to contrast recent trends with longer term ones, we have attempted to fit such models to data (i) over the longest time period possible to the present and (ii) since the mid to late 1980s. Data sources for these population estimates are provided in the tabulation, along with the time series for which the analysis is available. These are mostly provided from populations that have a 
population estimate data quality code in excess of 3 , given regular census of a more than half of the total population involved in the analysis. We here present the annual rate of change for significant regression models of population size on year, but in summary consider populations increasing by up to $3 \%$ per annum "increasing" and those increasing by $3.1 \%-6 \%$ as "rapidly increasing", those by $>6.1 \%$ as "very rapidly increasing", those with no trend as "stable" and those showing a significant decrease as "decreasing".

\section{Sources of annual population productivity and survival}

For several of the species, there exist annual assessments of the percentage of young birds in the winter population. First winter individuals of most species of geese can be separated from older adult birds on the basis of plumage, and these characteristics are widely known and accepted (see Cramp \& Simmons 1977). Knowledge of the relative breeding success in the population as a whole is an important demographic parameter (along with annual adult survival) for interpreting population change, so it was felt useful to present long term trends in this measure for those goose populations for which this statistic was available. The sampling of such data is fraught with problems, since family parties frequently assort themselves differently from those of non-breeding groups that typically contain very few young because of the tenacity of family groups that remain separate from large groups, at least during the first winter of life. Family parties tend to dominate optimal feeding opportunities, and are frequently more numerous on the outer edges of goose flocks for instance. Skilled and trained observers therefore try to sample age ratios in goose flocks in a manner that accounts for such potential sources of error and bias, but in presenting the age ratio data here, we take no account of how sampling problems may contribute to bias in these data. Rather we trust that the use of consistent techniques across many years provides an internal comparability within the data, providing trends that are not the result of systematic bias in the gathering of the annual age ratios. Finally, some groups and researchers have began using capture-mark-recapture techniques, generally using conspicuous collars or leg rings which can be re-read in the field without the need for recapture, to generate annual adult survival rates for some populations. Many of these studies have been published and so these are referenced as sources, but as with the time-series relating to trends in age-ratios, we here present these data on the assumption that the studies have been undertaken in a fashion that does not incorporate serious bias or error (either amongst the capture of individuals and their subsequent re-sighting, recapture or re-encounter) and specifically into the estimation of long term trends in annual adult survival. In presenting trends in reproductive success and annual adult survival rates, we differentiate between no trend (i.e. time does not significantly account for variance in the models), the significant contribution of time to modelling change (i.e. a significant increase or decrease) and a situation where the trend is unknown (time series too short or no significant contribution to the models).

\section{Results}

\section{Estimated population sizes}

The greatest conservation concern naturally involves the numerically rarest of the goose species in the region. Of these, the population at greatest risk of imminent extinction is the Scandinavian Lesser White-fronted Goose population, the smallest of all stocks in the Western Palearctic poised on the brink of extinction and subject of a major EU Life-Nature project (Tivanen et al. 2009), numbering very many less than 1000 individuals (Table 2). Only one other population, the Svalbard Lightbellied Brent Goose, has an estimated population size of less than 10,000 individuals (Table 2). Two further populations, the Greenland White-fronted and Russian Lesser White-fronted Geese, number fewer than 25,000 individuals in total, after which there follow five more populations with less than 50,000 individuals in all (Table 2). Four (possibly five) populations exceed half a million individuals.

\section{Adequacy of count coverage}

Twenty three out of the 29 populations considered here are secured a 4 or 5 estimate precision score, implying that for the vast majority of the population, we have adequate, or in many cases, very good coverage, totals and trends being based upon counts which cover more than half of the total populations in the majority of cases. Such coverage is extremely heartening in supporting effective interpretation of trends over longer time scales. There is a clear regional element to coverage quality, generally the very best coverage has been achieved over the longest time horizons in north and west Europe, whilst coverage is less good and 
Table 2. Status of the goose populations as assessed in 2009. Each population is defined by its breeding and winter range. Population size estimate for the mid-1990s (Madsen et al. 1999) and at the present time (with the time of the last estimate; all years in the 2000s). Q is the data quality code, see Table 1.

Status för gåsbestånden enligt bedömning 2009. Varje bestånd definieras av sitt häcknings- och vinterområde. Beståndsskattning för 1990-talet (Madsen m.fl. 1999) samt enligt senaste räkningar (med år för denna skattning; alla år på 2000-talet). Q är kvalitetskoden för data, se Tabell 1.

\begin{tabular}{|c|c|c|c|c|c|}
\hline $\begin{array}{l}\text { Population and } \\
\text { count month } \\
\text { Bestånd och } \\
\text { räkningsmånad }\end{array}$ & $\begin{array}{l}\text { Breeding } \\
\text { range } \\
\text { Häcknings- } \\
\text { område }\end{array}$ & $\begin{array}{l}\text { Winter } \\
\text { range } \\
\text { Vinter- } \\
\text { område }\end{array}$ & $\begin{array}{l}\text { Estimate } \\
\text { 1990s } \\
\text { Skattning } \\
\text { 1990-talet }\end{array}$ & $\begin{array}{l}\text { Most recent } \\
\text { estimate } \\
\text { Senaste } \\
\text { skattning }\end{array}$ & Q \\
\hline \multicolumn{6}{|l|}{ Bean Goose } \\
\hline Taiga (1) & Scandinavia/Russia & Baltic/Scotland & 100,000 & $63,000(8 / 9)$ & 4 \\
\hline Tundra I (1) & Scandinavia/Russia & Baltic/N. Sea & 600,000 & $522,000(7 / 8)$ & $4^{1}$ \\
\hline Tundra II (1) & Russia & C. Europe & $\mathrm{n} / \mathrm{a}$ (part of above) & $28,500(7 / 8)$ & 4 \\
\hline \multicolumn{6}{|l|}{ Pink-footed Goose } \\
\hline Iceland $(10 / 11)$ & Iceland/Greenland & UK & 250,000 & $350,000(8 / 9)$ & 5 \\
\hline Svalbard (11/1) & Svalbard & NW Europe & 37,000 & $63,000(8 / 9)$ & 5 \\
\hline \multicolumn{6}{|l|}{ White-fronted Goose } \\
\hline "Baltic-North Sea" (1) & Russia & NW Europe & 600,000 & $1,200,000(7 / 8)$ & $4^{2}$ \\
\hline "Pannonic" (1) & Russia & Central Europe & $10,000-40,000$ & $110,000(7 / 8)$ & 4 \\
\hline "Pontic/Anatolian" (1) & Russia & Greece/Turkey/ Black Sea & $350,000-700,000$ & 200,000 & 1 \\
\hline "Caspian" (1) & Russia & Caspian & $\mathrm{n} / \mathrm{a}$ & $\mathrm{n} / \mathrm{a}$ & 0 \\
\hline Greenland (3/4) & Greenland & Ireland/UK & 33,000 & $23,200(8 / 9)$ & 5 \\
\hline \multicolumn{6}{|c|}{ Lesser White-fronted Goose } \\
\hline Reintroduced & Sweden & Netherlands & $\mathrm{n} / \mathrm{a}$ & 120 & 4 \\
\hline Fennoscandia $(3 / 5 / 10 / 1$ & Fennoscandia & S/SE Europe & $100-150$ & $60-80(8 / 9)$ & 5 \\
\hline Russia (10/11) & Russia & Black/Caspian Sea & 15,000 & $10,000-21,000(8 / 9)$ & 4 \\
\hline \multicolumn{6}{|l|}{ Greylag Goose } \\
\hline Iceland (11/12) & Iceland/Greenland & Scotland & 80,000 & $98,000(8 / 9)$ & 5 \\
\hline Scotland (8/2) & Scotland & Scotland & 9,000 & $35,000(8 / 9)$ & 5 \\
\hline UK Feral (9) & UK & UK & 22,000 & $50,000(8 / 9)$ & $5^{3}$ \\
\hline NW Europe $(9 / 1)$ & NW Europe & NW/SW Europe & 200,000 & $610,000(7 / 8)$ & 4 \\
\hline C Europe (1) & C Europe & N Africa & 25,000 & $56,000(6 / 7)$ & 3 \\
\hline Black Sea & Black Sea & Black Sea & 85,000 & 85,000 & 1 \\
\hline SW Asia & W Siberia/Caspian & Caspian, Iran \& Iraq & $100,000+$ & $100,000+$ & 0 \\
\hline \multicolumn{6}{|l|}{ Canada Goose } \\
\hline UK (1) & UK & UK & 64,000 & $89,000(2000)$ & $5^{3}$ \\
\hline Scandinavia (1) & Scandinavia & NW Europe & 60,000 & $90,000(8 / 9)$ & 4 \\
\hline \multicolumn{6}{|l|}{ France/NL/Belgium, } \\
\hline \multicolumn{5}{|l|}{ Barnacle Goose } & 4 \\
\hline Greenland (3) & E Greenland & Ireland/UK & 40,000 & $70,500(7 / 8)$ & 5 \\
\hline Svalbard (11) & Svalbard & Scotland & 23,000 & $30,000(8 / 9)$ & 5 \\
\hline \multicolumn{6}{|l|}{ Russia/Baltic, } \\
\hline \multicolumn{6}{|l|}{ Brent Goose } \\
\hline Russia (DB) (1/5) & Russia & W Europe & 300,000 & $245,900(6 / 7)$ & 5 \\
\hline NE Canada (LB) (10) & NE Canada & Ireland & 20,000 & $40,000(8 / 9)$ & 5 \\
\hline Svalbard (LB) $(11 / 1 / 5)$ & Svalbard/Greenland & NW Europe & 5,000 & 7,600 (8/9) & 5 \\
\hline \multicolumn{6}{|l|}{ Red-breasted Goose } \\
\hline Russian (1) & Russia & Black Sea & 70,000 & $44,000(8 / 9)$ & $3 / 4^{2}$ \\
\hline
\end{tabular}

${ }^{1}$ Germany, Netherlands 5

${ }^{2}$ Improving Under förbättring

${ }^{3}$ Annual index Arligt index 
therefore interpretation of trends less easy based on the data to hand, in the eastern part of Europe and the eastern Mediterranean and Black Sea Regions, where count coverage could be considerably improved. This may not be especially a problem for the estimates presented here. For instance, for the Pannonic White-fronted Goose and Central European Tundra Goose, the count data are probably adequate to generate estimates of population size from those states providing good counts. Although data may be missing from some other states, these are known to be unlikely to constitute more than a few thousand birds, although this does not lessen the need to strength count networks and cross-border collaboration. The situation is not so good for the Central Greylag Goose population, where the cumulative sum of average counts from Czechia, Slovakia, Austria, Hungary, Italy, Croatia, Serbia, Tunisia and Algeria have been taken to provide an estimate of numbers present. However, Greylag Geese are now wintering regularly in Poland and ringing recoveries show that this species in some parts of Eastern Germany and Bavaria partly also belong to this population rather than the northwest European population. It is important that more concerted efforts assess the definitions of these flyways (using ringing and other techniques) and to design and coordinate count networks in a way that most effectively monitors their development in the future.

\section{Short- and long-term trends in abundance}

Most populations (16 out of 21 for which there are good data) show positive long-term trends, four were stable and the Scandinavian Lesser Whitefronted Goose has shown significant long-term decline (see Table 3 for a complete breakdown of these data). The situation is similar in the shorter term (18 populations showing increases since the early 1990s), but two other populations (Greenland White-fronted and Dark-bellied Brent Goose) show significant declines, both since the mid 1990s. In the short term, increases have been less rapid than in the longer term, suggesting some slowing of the rate of expansion in several populations in very recent years. Nevertheless, with the notable exceptions of the Lesser White-fronted Goose and Svalbard Light-bellied Brent Goose populations, it is apparent that most goose populations are sufficiently numerous $(>10,000$ individuals), widespread and of favourable conservation status in the Western Palearctic at the present time. Amongst the most numerous and still increasing stocks, the Bal-
tic/North Sea White-fronted Goose (1.2 million) is perhaps most evident in the NW European Greylag and Russian Barnacle Goose populations, both numbering well in excess of 500,000 individuals and increasing by at least $8 \%$ per annum (Table 3 ).

\section{Trends in reproductive success and annual adult survival rate}

Fifteen Western Palearctic goose populations are sampled annually for the proportions of young in their number, and for most of these, data are available from more than 25 years (several much longer, Table 4) With the notable exceptions of the Svalbard Pink-footed Goose (14.4\% young, 1980-2008) and Greenland White-fronted Goose (13\% young, 1982-2008), most Anser genus goose populations show a long term mean annual proportion of young above $20 \%$ and an overall long term decline in this statistic over time (Table 4). Although the Branta geese typically exhibit a lower proportion of young in their population in autumn (generally less than 18\%), most of these populations show declines or stable trends in reproductive output (Table 4).

At least 18 Western Palearctic goose populations have an associated banding scheme of some kind that provides marked individuals to support a capture-mark-recapture estimation of annual adult survival (Table 4). Data from the Anser species show annual survival to be generally lower (75-86\%) than amongst Branta species (84-95\%), a factor partly reflecting their relative exposure to hunting in recent decades, but also compensated for in terms of differential long term productivity.

\section{Discussion}

\section{Monitoring coverage}

We are fortunate indeed to be able to benefit from the tremendous legacy left by the pioneers who started to establish mechanisms to monitor waterbird populations following the Second World War in Europe in response to the concern about the viability of stocks of migratory waterbirds, including geese, at that time. These foundations have provided us with contemporary data series relating to goose abundance which now stretch back over more than 50 years. Such time series relating to wild populations remain rare in biology and therefore of increasing value as the series accumulate. Because geese are long-lived, these long and reliable time series give a unique insight into the development of populations on a large geographical 
Table 3. Trends in the size of the goose populations as assessed in 2009, given in the short and longer term (different lengths of time series available limits inter-population comparisons). Rate of change is the slope of the logarithmically transformed annual total population estimates against time.

Populationstrender bedömda 2009. Förändringens hastighet är lutningen för de logaritmerade årliga värdena för beståndsstorleken mot tiden.

\begin{tabular}{|c|c|c|c|}
\hline Population & $\begin{array}{l}\text { Long term trend } \\
\text { Långtidstrend }\end{array}$ & $\begin{array}{l}\text { Short term trend } \\
\text { Korttidstrend }\end{array}$ & $\begin{array}{c}\text { Source }^{1} \\
\text { Källa }\end{array}$ \\
\hline \multicolumn{4}{|l|}{ Bean Goose } \\
\hline Taiga (1) & ?stable & decline since 1999 & 1 \\
\hline Tundra I (1) & ?increasing & $+4.4 \%$ since 1989 & 1 \\
\hline Tundra II (1) & ?decreasing & decline since 1989 & 1 \\
\hline \multicolumn{4}{|l|}{ Pink-footed Goose } \\
\hline Iceland $(10 / 11)$ & $+3.9 \%$ since 1950 & $+2.8 \%$ since 1995 & 2 \\
\hline Svalbard (11/1) & $+3.3 \%$ since 1965 & $+4.4 \%$ since 1995 & 3 \\
\hline \multicolumn{4}{|l|}{ White-fronted Goose } \\
\hline "Baltic-North Sea" (1) & $+7.7 \%$ since 1958 & $+2.9 \%$ since 1995 & 4 \\
\hline "Pannonic" (1) & not available & not available & WI \\
\hline "Pontic/Anatolian" (1) & not available & not available & WI \\
\hline "Caspian" (1) & not available & not available & WI \\
\hline Greenland (3/4) & $+1.1 \%$ since 1983 & $-3.0 \%$ since 1999 & 5 \\
\hline \multicolumn{4}{|l|}{ Lesser White-fronted Goose } \\
\hline Scandinavia $(3 / 5 / 10 / 11)$ & $-4.6 \%$ since 1993 & $-5.0 \%$ since 2000 & 6 \\
\hline Russia (10/11) & ?stable & ?stable & 6 \\
\hline \multicolumn{4}{|l|}{ Greylag Goose } \\
\hline Iceland (11/12) & $+2.6 \%$ since 1960 & $+1.0 \%$ since 1995 & 2 \\
\hline Scotland $(8 / 2)$ & not available & $+10.8 \%$ since 1997 & 7 \\
\hline UK Feral (9) & $+8.6 \% 1976-1991$ & +9.4\% since 1988 & 7,8 \\
\hline NW Europe (9/1) & $+8.5 \%$ since 1980 & +9.1\% since 1995 & 4,9 \\
\hline C Europe (1) & not available & $+6.8 \%$ since 1995 & WI \\
\hline Black Sea & not available & not available & WI \\
\hline SW Asia & not available & not available & WI \\
\hline \multicolumn{4}{|l|}{ Canada Goose } \\
\hline UK (1) & +9.3\% since 1988 & $+9.3 \%$ since 1988 & 8 \\
\hline Scandinavia (1) & $+10.8 \%$ since 1977 & $+10.3 \%$ since 1998 & 10 \\
\hline France/NL/Belgium/Germany (1) & not available & $+14.0 \%$ since 1999 & 15 \\
\hline \multicolumn{4}{|l|}{ Barnacle Goose } \\
\hline Greenland & $+3.5 \%$ since 1956 & $+3.7 \%$ since 1987 & 7 \\
\hline Svalbard & $+6.6 \%$ since 1956 & $+2.3 \%$ since 1987 & 7 \\
\hline Russia/Baltic/NorthSea & $+7.8 \%$ since 1960 & $+7.8 \%$ since 1995 & 4,11 \\
\hline \multicolumn{4}{|l|}{ Brent Goose } \\
\hline Russia (DB) & $+6.1 \%$ since 1956 & $-1.4 \%$ since 1991 & 4 \\
\hline NE Canada (LB) & $+2.2 \%$ since 1960 & $+8.3 \%$ since 1995 & 12 \\
\hline Svalbard (LB) & $+3.5 \%$ since 1965 & $+2.8 \%$ since 1995 & 13 \\
\hline \multicolumn{4}{|l|}{ Red-breasted Goose } \\
\hline Russia & $+4.2 \%$ since 1954 & $-4.6 \%$ since 1995 & 14 \\
\hline
\end{tabular}

${ }^{1}$ Sources: 1. Heinicke, T. (unpubl.); 2. Mitchell (2009); 3. Madsen, J. (unpubl.); 4. Ebbinge (2009); 5. Fox et al. (2009a); 6. Aarvak, T. (unpubl.); 7. WWT/Mitchell, C.; 8. Rehfisch et al. (2002); 9. Nilsson, L. (unpubl.); 10. Based on November counts in Sweden and Germany, Nilsson, L. and Heinicke, T (unpubl.) - totals do not include NL and B; 11. Henk van der Jeugd (unpubl.);12. WWT/Kendrew Colhoun (unpubl.); 13. Preben Clausen (unpubl.); 14. Red-breasted Goose International Working Group/Sergey Dereliev (unpubl.); 15 Hustings et al. (2009), Voslamber et al. (2010), Anselin \& Devos (2005), Fouque \& Schricke (2010); WI indicates data interpolated from Wetlands International International Waterbird Count database. 
Table 4. Trends in productivity and survival amongst the goose populations. Key: $\mathrm{TP}=$ Trend in productivity, $\mathrm{TS}=$ Trend in survival. The trends are given as declining $(-)$, increasing $(+)$ or not significant $(0)$.

Ungproduktion och överlevnad för gåspopulationerna. TP=trend för ungproduktionen, TS=trend för överlevnaden. Trenderna anges som minskande (-), ökande (+) eller ej signifikant (0).

\begin{tabular}{|c|c|c|c|c|c|c|}
\hline Population & $\begin{array}{l}\text { Mean \% young } \\
\text { (range available) } \\
\text { Medel \% ungar } \\
\text { (mätperiod) }\end{array}$ & $\mathrm{TP}$ & $\begin{array}{l}\text { Banding } \\
\text { started } \\
\text { Märkning } \\
\text { började }\end{array}$ & $\begin{array}{l}\begin{array}{l}\text { Survival \% } \\
\text { (range available) } \\
\text { Överlevnad \% } \\
\text { (mätperiod) }\end{array} \\
\end{array}$ & TS & $\operatorname{Ref}^{2}$ \\
\hline \multicolumn{7}{|l|}{ Bean Goose } \\
\hline Taiga & $?$ & ? & $(1970 \mathrm{~s})$ & not analysed & ? & a \\
\hline Tundra I & $19.8(1981-2008)$ & - & $(1970 s)$ & not analysed & $?$ & $\mathrm{~b}$ \\
\hline \multicolumn{7}{|l|}{ Tundra II } \\
\hline \multicolumn{7}{|l|}{ Pink-footed Goose } \\
\hline Iceland & $20.3(1950-2008)$ & - & $(1980 \mathrm{~s})$ & $81(1987-2001)$ & 0 & 1 \\
\hline Svalbard & $14.4(1980-2008)$ & - & $(1980 \mathrm{~s})$ & $86(1989-2002)$ & 0 & 2 \\
\hline \multicolumn{7}{|l|}{ White-fronted Goose } \\
\hline "Baltic-North Sea" & $27.5(1957-2007)$ & - & $(1990 s)$ & $75(1958-1969)$ & + & 3 \\
\hline \multicolumn{7}{|l|}{ "Pannonic" } \\
\hline \multicolumn{7}{|l|}{ "Pontic/Anatolian" } \\
\hline \multicolumn{7}{|l|}{ "Caspian" } \\
\hline Greenland & $13(1982-2007)$ & - & $(1970 s)$ & $82(1982-2007)$ & + & 4 \\
\hline \multicolumn{7}{|c|}{ Lesser White-fronted Goose } \\
\hline Fennoscandia $^{1}$ & 51.1(1981-2008) & - & (1995) & Yes, unpublished & ? & 5 \\
\hline Russia & $?$ & $?$ & $(2000 s)$ & No & $?$ & \\
\hline \multicolumn{7}{|l|}{ Greylag Goose } \\
\hline Iceland & $20.7(1960-2008)$ & 0 & (1990s) & $72(1992-2001)$ & 0 & 1 \\
\hline Scotland & $29(1998-2006)$ & 0 & (1980s) & $74(1998-2006)$ & 0 & 6 \\
\hline UK Feral & not available & $?$ & (local) & not analysed & $?$ & \\
\hline NW Europe & not available & $?$ & (1970s) & 75-85 (1984-2004) & - & 7 \\
\hline C Europe & not available & $?$ & (1970s) & $?$ & ? & \\
\hline \multicolumn{7}{|l|}{ Black Sea } \\
\hline \multicolumn{7}{|l|}{ SW Asia } \\
\hline \multicolumn{7}{|l|}{ Canada Goose } \\
\hline UK & not available & $?$ & $(1980 \mathrm{~s})$ & not analysed & ? & \\
\hline Scandinavia & $?$ & $?$ & (1980s) & $?$ & $?$ & \\
\hline \multicolumn{7}{|l|}{ France/NL/Belgium/Germany } \\
\hline \multicolumn{7}{|l|}{ Barnacle Goose } \\
\hline Greenland & $11.6(1959-2007)$ & - & $(1960 \mathrm{~s})$ & not analysed & ? & 8 \\
\hline Svalbard & $15.7(1958-2006)$ & - & (1970s) & $90(1975-1993)$ & 0 & 9 \\
\hline Russia/Baltic/NorthSea & $15.8(1974-2008)$ & 0 & (1970s) & $95(1984-1996)$ & 0 & 10 \\
\hline \multicolumn{7}{|l|}{ Brent Goose } \\
\hline Russia (DB) & $17.7(1956-2006)$ & $0(-)$ & (1970s) & $84(1973-1990)$ & - & 11 \\
\hline NE Canada (LB) & $14.7(1960-2008)$ & $0(-)$ & (1980s) & not analysed & $?$ & 12 \\
\hline Svalbard (LB) & $12.9(1980-2008)$ & $0(-)$ & (1980s) & 87 (1991-1999) & 0 & 13 \\
\hline \multicolumn{7}{|l|}{ Red-breasted Goose } \\
\hline Russia & 25.5 (5yrs 1996-2005) & ? & (not since 1990s) & $?$ & $?$ & 14 \\
\hline
\end{tabular}

${ }^{1}$ the Valdak population

${ }^{2}$ References: a. SOVON: supplied by Leo van den Bergh and others, some question over correct determination of race; b. SOVON: supplied by Leo van den Bergh and others, considered reliable; 1. Frederiksen et al. (2004); 2. Kery et al. (2006); 3. Ebbinge (1991); 4. GWGS unpublished data; 5. Tivanen et al. (2009); 6. Trinder et al.(2009); 7. Pistirius et al (2007), Nilsson \& Persson (1993), Voslamber et al. (2007); 8. WWT/Carl Mitchell; 9. WWT and Black et al. (2007); 10. Larsson et al. (1998); 11. Ebbinge (1992); 12. WWT; 13. Clausen et al. (2001); 14. Red-breasted Goose International Working Group/Sergey Dereliev (unpubl.) 
scale, especially as the extent of good and reliable coverage increases.

It is clear that the geographical coverage achieved is best in the north and west of Europe, with the UK, North Sea and Baltic regions being especially highly organised in achieving extensive coverage of all the populations occurring there. After the excellent coverage achieved in the prelude to the publication of the major review of Madsen et al. (1999), coverage in central and eastern Europe has not been maintained at the same level as in earlier years, with the result that although the national schemes of nations such as Czech Republic, Austria and Hungary continue to deliver very high quality nationally coordinated goose surveillance schemes, gaps are beginning to appear in coverage in other states, making confident compilation of population totals difficult in recent years, with the result that we cannot be confident about determining the size of the "Pannonic" White-fronted Goose and Central European Greylag Goose populations. The situation is no better in the eastern Mediterranean and the Black Sea, where coverage is probably extremely good, but coordination and reporting to any centralised database facility in recent years has fallen into disrepair.

As a result of this unfortunate situation, we lack good robust population estimates and trends over recent decades for 5 populations, namely the Pontic/Anatolian and Caspian White-fronted Goose populations and the Central European, Black Sea and SW Asia flyway populations of the Greylag Goose. Our woefully inadequate knowledge of their distribution and abundance necessitates urgent action. In addition, we could improve the count data quality which underpins the Red-breasted Goose monitoring programme, not least because of the apparent declines in their number since the late 1990s. Finally, the network could further benefit with improvements in planning, coordination and collaboration of counting protocols to improve our knowledge of all populations of Bean Geese, the Baltic/North Sea White-fronted Goose, Russian Lesser White-fronted Goose and all continental Greylag Goose populations.

It was very evident from the results of this exercise to collate the count data that there is a very urgent need to re-establish the close working relationship that existed in the 1990s between the Goose Specialist Group, the IWC database, the population experts involved in collating goose population monitoring data and the IWC and GSG national coordinators that former coordinated the counting and reporting of the goose surveillance systems.

\section{Timing of monitoring}

Traditionally, much of the goose monitoring has been focussed upon the mid-January counts which are the focus of the IWC. However, it is very clear that more accurate population size assessments are achieved by counting at other times, especially in spring or autumn when geese may be more concentrated, or for some other reason are easier to count. As is evident from Table 2, 17 of the 29 populations considered here are now monitored at times other than mid-January. It is important in considering future monitoring programmes for those populations for which we currently have poor, inadequate or no coverage should be designed with a view to selecting the best possible period for monitoring a given population.

\section{Overall status and trends}

Our assessment suggests that there are now 4.77 million geese wintering in the Western Palearctic (excluding the introduced, feral, escaped and reintroduced populations of the region), in excess of 5.04 million geese in all, up substantially on 3.1 million estimated in January 1993 (Madsen et al. 1996) and 3.3 million at the time of the Madsen et al. (1999) review. We are more confident that whilst some of the increases can be accounted for by improvements in coverage, the vast majority of this increase is the result of increases in the numbers of most populations. Those making a particular numerical contribution to overall increases since Madsen et al. (1999) are an extra 700,000 Baltic/North Sea White-fronted Geese, 433,000 extra Russia/Baltic/NorthSea Barnacle Geese, 410,000 more NW European Greylag Geese and another 100,000 Iceland Pink-footed Geese (Table 2). Sixteen out of 21 populations for which we have good data show significant increases both since the 1950s and 1960s, but also in the shorter term since the early 1990s (Table 3 ). Only the Scandinavian Lesser White-fronted and Svalbard Light-bellied Geese number less than 10,000 individuals and both show unfavourable conservation status, the former being highly threatened because of the critically small population size and range. Although Greenland White-fronted Geese have shown recent declines (as a result of a series of very low reproductive years, Boyd \& Fox 2008), under protection from hunting in Iceland, numbers have shown some signs of recovery, at least not declining so rapidly (Fox et al. 2009a). Redbreasted Geese have shown rather dramatic de- 
clines in number in recent years, and it is clear that this population needs conservation attention, both to appraise the necessary level of monitoring and to address the causes of the declines in abundance if this proves to be the case. Taiga Bean Geese may also be showing signs of decline, but urgent attention needs to be paid to improving count coverage before we can be truly confident of the current population size, distribution and trends, discussed in greater depth elsewhere in this volume (Heinicke 2010). Dark-bellied Brent Geese are also showing very recent declines in number after a prolonged period of increase under protection from hunting exploitation on the winter quarters. The reasons for this are not currently obvious, although poor reproduction in recent years has played some part since the collapse of the "boom and bust" reproductive cycle linked to changes in abundance of the lemming predators on the breeding grounds (e.g. Ebbinge \& Spaans 2002). Because of their numerical size, all these populations are not threatened with extinction, but clearly investigation of the causes behind the declines could flag up potential appropriate conservation management actions that could potentially restore these populations to favourable conservation status.

With these exceptions, all of the other wild goose populations in the Western Palearctic which are monitored well enough to generate long term trends show uninterrupted exponential increases in number, with few signs of slowing their rate of increase. Studies of breeding and wintering habitat availability have only really been carried out on large spatial scales for the Svalbard Pink-footed Goose population (Jensen et al. 2008 and Wisz et al. 2008a respectively), but these suggest that, under current scenarios, there are adequate unexploited habitats to support further expansion of that particular goose population, although clearly such habitats are finite and may change in relation to contrasting economic pressures on land use in Europe (Wisz et al. 2008a). In Svalbard, grazing Pink-footed and Barnacle Geese can cause changes in plant community structure and productivity and increase carbon dioxide release from the tundra (Loonen \& Solheim 1998, Van der Wal et al. 2007) potentially affecting the availability of quality habitat through some density dependence regulatory mechanism (Wisz et al. 2008b). Likewise, competition between expanding formerly alloptaric goose populations may bring about increased overlap in distributions, habitat and ultimately diet, enhancing competitive interactions between populations, although in studied situations, this seems unusual and impacts at the population level are hard to demonstrate (e.g. Kristiansen \& Jarrett 2002, Fox et al. 2009b). The declines that we note here in reproductive output may be the first demographic signs of such factors impinging on the expansion rate of these populations. However, the art of forecasting the future development of goose population size is difficult, and the recent history is littered with poor or inaccurate forecasts of how populations will increase or otherwise in the future. What is clear is that herbivorous geese have shown themselves very adept at adapting to exploiting the rich monocultures of specially bred cereal, root and grass crops which our agricultural domination of temperate landscapes provide in vast amounts in contemporary Europe, and we should therefore be prudent and expect that the increases we have seen amongst the more common species in very recent years to continue, at least in the very near future. This is likely to continue to bring new challenges with regard to resolving ever increasing conflicts between maintaining population distribution and abundance and reconciling economic loss to farmers and other interests. For this reason, it would appear essential to continue the rich tradition of monitoring of these organisms as we have done in the recent past, but by supplementing an improved coordinated network of counters integrated into an effective database system with improved demographic monitoring to enable us to understand the population processes involved in determining the observed trends.

\section{The nature of future monitoring}

Just in the relatively short time since the publication of Madsen et al. (1999), the network of coordinated goose counters throughout Europe has lost a large degree of its international coordination. This has been offset to some extent by the continuation of national count schemes that continue to gather data for domestic purposes. However, the results of this analysis clearly show that gathering local data may not be the best way to compile flyway-wide surveillance data for tracking specific populations. This is especially the case where cross-border coordination is essential to avoid missed or doublecounted birds, as is the case regarding Red-breasted Geese in Bulgaria and Romania, where efforts to coordinate counting in the two states have been highly successful in recent years. Former close collaboration between count networks was essential between Poland and Germany and between France and Germany, as elsewhere, is especially impor- 
tant because night time roosts are inevitably along rivers and floodplain systems that lie along shared international boundaries. Counting roost aggregations brings its own problems, not least if inexperienced observers are confronted with very large goose aggregations that can be visually confusing and risk lack of identification or misidentification of species. The synthesis here also underlined our complete loss of goose count coverage since the 1990s, for example in many parts of Poland, where coverage was formerly good. It is very evident from the first tentative steps here to identify where the gaps in the current count network exist, and it is important that Wetlands International in partnership with the Goose Specialist Group attempt to review the coverage and the strategic need for reestablishment and refreshing of the goose count network throughout the region. Given the increasing problems of identifying discrete populations, this needs some assessment of flyway definitions (e.g. through ringing, telemetry, genetic or other methods for establishing how individual migration routes contribute to describing the flyways of populations). Even having established relatively robust count systems, we still need to interpret simple changes in distribution and abundance - are they to do with changes in mortality, survival, emigration, immigration or a combination of all these? These questions require demographic monitoring, much of which is already in hand for some populations, based on long-term age ratio sampling and capture-recapture marking studies. In particular, we consider it essential that current marking schemes (which have been very successful in generating resightings from observers) be continued and greatly extended to generate data on individual survival and reproductive success that can provide invaluable demographic monitoring data that enables us to interpret observed changes in numbers. We also encourage those schemes which hold such data to analyse these datasets to further extend our current understanding of goose stocks in the Western Palearctic and their future development. Finally, it important that urgent consideration is given to extending the existing monitoring of goose populations to other introduced (i.e. both native and alien) goose species, as invasive and alien taxa are being recognised as a biodiversity issue. What is clear is that we need to review the status of goose monitoring in the Western Palearctic and to develop clear proposals for how to improve the current system to better meet current and future needs.

\section{Acknowledgements}

We are hugely grateful to the vast army of folk that have contributed to this very major synthesis of available information. We are especially grateful to the very many people who have provided their knowledge or data for our use and who have provided information about the status of particular populations. Without the selfless investment of thousands of counters and coordinators going back several years, no such overview would be possible. Finally, thanks to Simon Delany and Nicky Petkov at Wetlands International for supply of data from the IWC database. Hearty thanks to you all!

\section{References}

Anselin A. \& Devos K. 2005. Wintertellingen van verwilderde ganzen in Vlaanderen met bijzondere aandacht voor de Canadese Gans Branta canadensis. Natuur Oriolus 71: 90-102.

Black, J.M., Prop, J. \& Larsson, K. 2007. Wild Goose Dilemmas. Branta Press, Groningen. Netherlands.

Boyd, H. \& Fox, A.D. 2008. Effects of climate change on the breeding success of White-fronted Geese Anser albifrons flavirostris in west Greenland. Wildfowl 58: 55-70.

Clausen, P., Frederiksen, M., Percival, S.M., Anderson, G.Q.A. \& Denny, M.J.H. 2001. Seasonal and Annual Survival of East-Atlantic Pale-Bellied Brent Geese Branta hrota Assessed by Capture-Recapture Analysis. Ardea 89: 101-112.

Cramp, S. \& Simmons, K.E.L. (eds.) 1977. Birds of the Western Palearctic. Volume 1. University Press, Oxford.

Delany, S. \& Scott, D. 2002. Waterbird Population Estimates - Third Edition. Wetlands International, Wageningen, The Netherlands.

Delany, S. \& Scott, D. 2006. Waterbird Population Estimates - Fourth Edition. Wetlands International, Wageningen, The Netherlands.

Ebbinge, B.S. 1991. The impact of hunting on mortality rates and spatial distribution of geese wintering in the Western Palearctic. Ardea 79: 197-209.

Ebbinge, B.S. 1992. Regulation of numbers of Dark-bellied Brent Geese Branta b. bernicla on spring staging sites. Ardea 80: 203-228.

Ebbinge, B.S. 2009. Evaluatie Opvangbeleid 2005-2008 overwinterende ganzen en smienten. Deelrapport 4. Invloed opvangbeleid op de internationale verspeiding van overwinterende ganzen in NW-Europa. Alterra-rapport 1842, Wageningen University. Netherlands. (In Dutch)

Ebbinge, B.S. \& Spaans, B. 2002. How do Brent Geese (Branta b. bernicla) cope with evil? Complex relationships between predators and prey. Journal of Ornithology 143: 33-42.

Fox, A.D., Francis, I.S. \& Walsh, A.J. 2009a. Report of the 2008/9 International Greenland White-fronted Goose Census. GWGS/Irish National Parks and Wildlife Service.

Fox, A.D., Eide, N., Bergersen E. \& Madsen, J. 2009b. Resource partition in sympatric arctic geese: summer spatial segregation, habitat use and diet overlap of barnacle and 
pink-footed geese in Svalbard. Ibis 151: 122-133.

Frederiksen, M., Hearn, R.D., Mitchell, C., Sigfússon, A., Swann, R.L. \& Fox, A.D. 2004. The dynamics of hunted Icelandic goose populations: a reassessment of the evidence. Journal of Applied Ecology 41: 315-334.

Hearn, R.D. \& Mitchell, C.R. 2004. Greylag Goose Anser anser (Icelandic population) in Britain and Ireland 1960/61-1999/2000. Waterbird Review Series, The Wildfowl \& Wetlands Trust/Joint Nature Conservation Committee, Slimbridge.

Hustings F., Koffijberg K., van Winden E., van Roomen M., SOVON Ganzen- en Zwanenwerkgroep \& Soldaat L. 2009. Watervogels in Nederland in 2007/2008. SOVONmonitoringrapport 2009/02. SOVON Vogelonderzoek Nederland, Beek-Ubbergen.

Jensen, R.A., Madsen, J., O'Connell, M., Wisz, M.S., Tømmervik, H. \& Mehlum, F. 2008. Prediction of the distribution of Arctic-nesting pink-footed geese under a warmer climate scenario. Global Change Biology 14: 1-10.

Kery, M., Madsen, J. \& Lebreton, J.D. 2006. Survival of Svalbard pink-footed geese Anser brachyrhynchus in relation to winter climate, density and land-use. Journal of Animal Ecology 75: 1172-1181.

Kristiansen, J.N. \& Jarrett, N.S. 2002. Inter-specific competition between Greenland White-fronted Geese Anser albifrons flavirostris and Canada Geese Branta canadensis interior moulting in West Greenland: mechanisms and consequences. Ardea 90: 1-13.

Larsson, K., van der Jeugd, H.P., van der Veen, I.T. \& Forslund, P. 1998. Body size declines despite positive directional selection on heritable size traits in a barnacle goose population. Evolution 52: 1169-1184.

Loonen, M.J.J.E. \& Solheim, B. 1998. Does arctic vegetation change when grazed by barnacle geese? A pilot study. Norsk Polarinstitut Skrifter 200: 99-103.

Madsen, J., Reed, A. \& Andreev, A. 1996. Status and trends of geese (Anser sp., Branta sp.) in the world: a review, updating and evaluation. Gibier Faune Sauvage 13: 337353.

Madsen, J., Cracknell, G. \& Fox, A.D. (eds.) 1999. Goose Populations of the Western Palearctic. A review of status and distribution. Wetlands International Publ. 48, Wetlands International, Wageningen, The Netherlands. National Environmental Research Institute, Rønde, Denmark. $344 \mathrm{pp}$.

Mitchell, C. 2009. Status and distribution of Icelandic breeding geese: results of the 2008 international census. Wildfowl \& Wetlands Trust report, Slimbridge.

Mitchell, C.R. \& Hearn, R.D. 2004. Pink-footed Goose Anser brachyrhynchus (Greenland/Iceland population) in Britain and Ireland 1960/61-1999/2000. Waterbird Review Series, The Wildfowl \& Wetlands Trust/Joint Nature Conservation Committee, Slimbridge.

Mitchell, C.R., Walsh, A.J., Hall, C. \& Crowe, O. 2008. Greenland Barnacle Geese Branta leucopsis in Britain and Ireland: Results of the international census, spring 2008. Wildfowl \& Wetlands Trust, Slimbridge.
Nilsson, L. \& Persson, H. 1993. Variation in survival in an increasing population of the Greylag Goose Anser anser in Scania, southern Sweden. Ornis Svecica 3: 137-146;

Pistirius, P.A., Follestad, A., Nilsson, L. \& Taylor, F.E. 2007. A demographic comparison of two Nordic populations of Greylag Geese Anser anser. Ibis 149: 553-563

Rehfisch et al. 2002. An approach to the assessment of change in numbers of Canada Geese and Greylag Geese in southern Britain. Bird Study 49: 50-59.

Robinson, J.A., Colhoun, K., Gudmundsson, G.A., Boertmann, D, Merne, O.J., O'Briain, M., Portrig, A.A., Mackie, K. \& Boyd, H. 2004. Light-bellied Brent Goose Branta bernicla hrota (East Canadian High Arctic population) in Britain and Ireland 1960/61-1999/2000. Waterbird Review Series, The Wildfowl \& Wetlands Trust/Joint Nature Conservation Committee, Slimbridge.

Scott, D.A. \& Rose, P.M. 1996. Atlas of Anatidae Populations in Africa and Western Eurasia. Wetlands International Publication No.41, Wageningen, The Netherlands.

Thorup, O. 2006. Breeding Waders in Europe 2000. International Wader Studies 14. Internternational Wader Study Group, UK.

Tivanen, P., Øien, I.J. \& Ruokolainen, K. (eds.) 2009. Conservation of Lesser White-fronted Goose on the European migration route. Final Report of EU Life-Nature project. WWF Finland/NOF Norway report. Helsinki-Trondheim.

Trinder, M., Mitchell, C. \& Bowler, J. 2009. An assessment of the status of the native Greylag Goose (Anser anser) population in Scotland and an analysis of future trends based on population modelling. Report to Scottish Natural Heritage. Wildfowl \& Wetlands Trust, Slimbridge.

Van der Wal, R., Sjögersten, S., Woodin, S.J., Cooper, E.J., Jónsdóttir, I.S., Kuijper, D., Fox, A.D. \& Huiskes, A.D. 2007. Spring feeding by pink-footed geese reduces carbon stocks and sink strength in tundra ecosystems. Global Change Biology 13: 1-7.

Voslamber, B., van der Jeugd H. \& Koffijberg K. 2007. Aantallen, trends en verspreiding van overzomerende ganzen in Nederland. Limosa 80: 1-17.

Voslamber B., van der Jeugd H. \& Koffijberg K. 2010. Broedende ganzen in Nederland. De Levende Natuur 111: 40-44.

Willems, F. \& van Houwlingen, G. 2007. Trekgedrag en overleving van Grauwe Ganzen Anser anser in de Ooijpolder. Limosa 76:117-122.

Wisz, M.S., Dendoncker, N., Madsen, J., Rounsevell, M., Jespersen, M., Kuijken, E., Courtens, W., Verscheure, C., Cottaar, F. 2008a. Modelling pink-footed goose ( $\mathrm{An}$ ser brachyrhynchus) wintering distributions for the year 2050: Potential effects of land use-change in Europe. $D i$ versity and Distributions. 14: 721-731.

Wisz, M.S., Tamstorf, M., Madsen, J. \& Jespersen, M. 2008b. Where might the western Svalbard tundra be vulnerable to pink-footed goose (Anser brachyrhynchus) population expansion? Clues from species distribution models. Diversity and Distributions. 14: 26-37. 